\title{
Data Network Security Over The Horizon Radar
}

\author{
Lecturer, Tarek Ibrahim H. Melad, Training Management of Libyan Army
}

DOI: 10.29322/IJSRP.11.07.2021.p11598

http://dx.doi.org/10.29322/IJSRP.11.07.2021.p11598

Abstract- As opposed to microwave signal which coverage is restricted to LOS propagation, HF signal can propagate over-the-horizon (OTH).The Exclusive Economic Zone (EEZ) of a country spans $200 \mathrm{NM}$ from its shore and it requires constant surveillance in order for that country to know the locations, identifications and activities of all the ships within it. Potential threats could be various, like illegal fishing, illegal immigration, smuggling, terrorism, theft of goods and oil from transport ships and tankers.

In order to combat illegal activities in proper ways, most important is to be aware of it. This could be achieved with OTHR, and Command and Control Center which would automatically trace all offshore activities, and warn for suspicious ones.

The Exclusive Economic Zone (EEZ) of a country spans 200 NM from its shore and it requires constant surveillance in order for that country to know the locations, identifications and activities of all the ships within it.

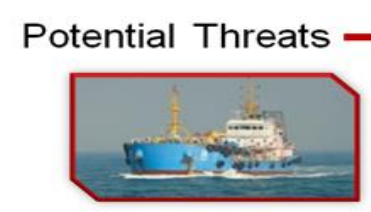

Illegal Fishing

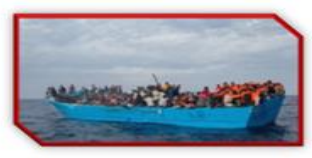

Illegal Immigration

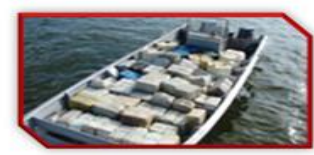

Smuggling

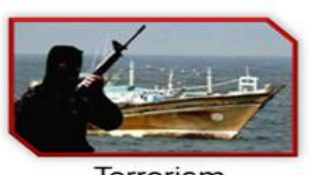

Terrorism

How to Combat
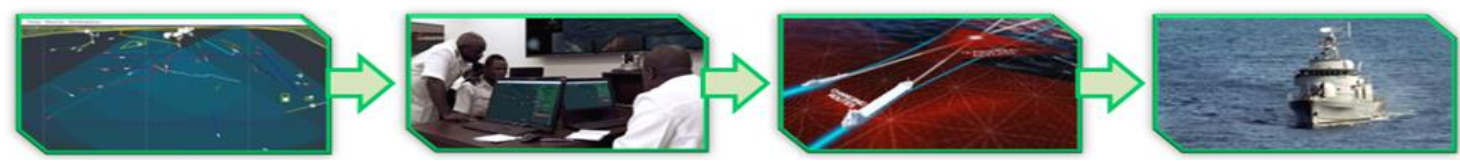

Index Terms- Network security, Uninterrupted Maritime Surveillance, Key Features, Radar Cross Section (RCS), HF-OTHR Hardware and Antennas, FCR - Frequency Control Rack, Transmitting Antenna Array, Data Integration Algorithm

\section{INTRODUCTION}

\section{Qurveillance Options in Network security}

There are several maritime surveillance options available:

- Land-based microwave radars, up to $60 \mathrm{~km}$ from the shore, constant tracking

- Ship-based microwave radars, up to $40 \mathrm{~km}$ from the ship, constant tracking

- Airborne radars, $40 \mathrm{~km}$ surveillance zone, tracking limited to flight time

- Space-based radars, $11 \mathrm{~km}$ swath, tracking updates every 3 hours

- Land-based HFSW (HF-OTHR) radars, up to $360 \mathrm{~km}$ from the shore, constant tracking

HF-OTHR radar is offering largest constant coverage zone. 


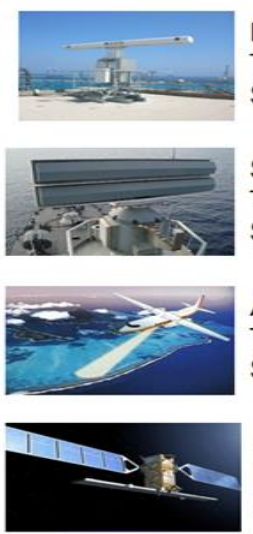

Land-based microwave radars

Tracking - Constant

Surveillance zone - up $60 \mathrm{~km}$ from the shore

Ship-based radars

Tracking - Constant

Surveillance zone - up $40 \mathrm{~km}$ from the ship

\section{Airborne radars}

Tracking - Intermittent (limited flight time)

Surveillance zone $-100 \mathrm{~km}$

Space-based radars

Tracking - Updates every 3 hours

Surveillance zone $-11 \mathrm{~km}$ swath

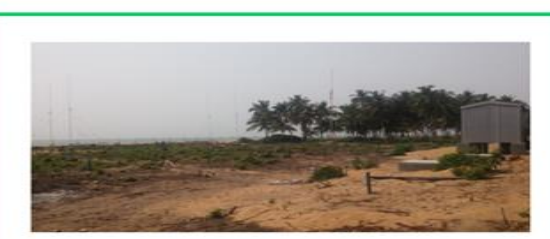

Land-based HFSW radar

Tracking - Constant

Surveillance zone - up to

$360 \mathrm{~km}$ from the shore

\section{Figure 2 Surveillance Options}

\section{Theoretical Background and Principles of Operation of Network Security}

HF-OTHR operates in HF spectra: 3-30MHz. Exact frequency selection depends on specific requirements: range, targets of interest, frequency licensing - and is fully customizable).

HF signal is propagated over the ocean water surface, and it can reach beyond the line-of-sight. This is the most important difference between HF radar and standard microwave surveillance radars.

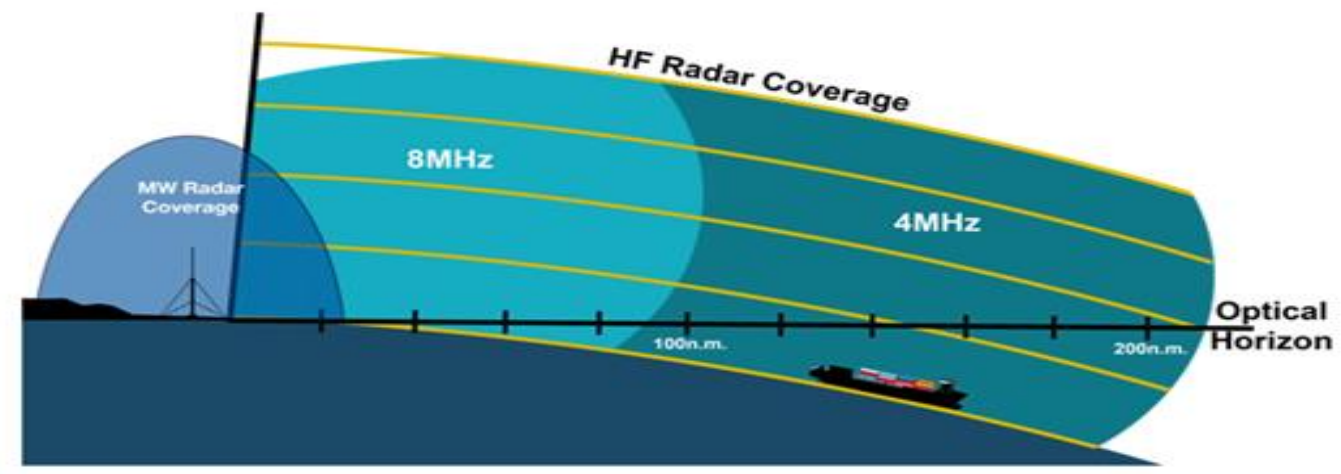

Figure 3 Principles of Operation

\section{Network Security and Site Geometry} below.

Site organization for the best coverage $(\sim 200 \mathrm{~nm})$, with operating frequency at $4.6 \mathrm{MHz}$ and corresponding site dimensions is shown

If smaller range is requested, system can work at higher frequency, with smaller antennas and less space required.

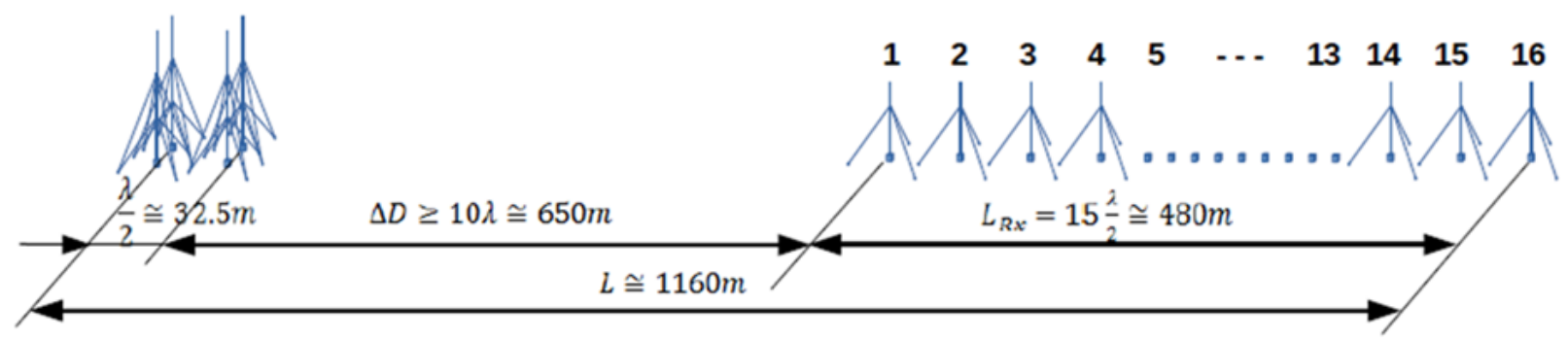

Figure 4 Typical site geometry 


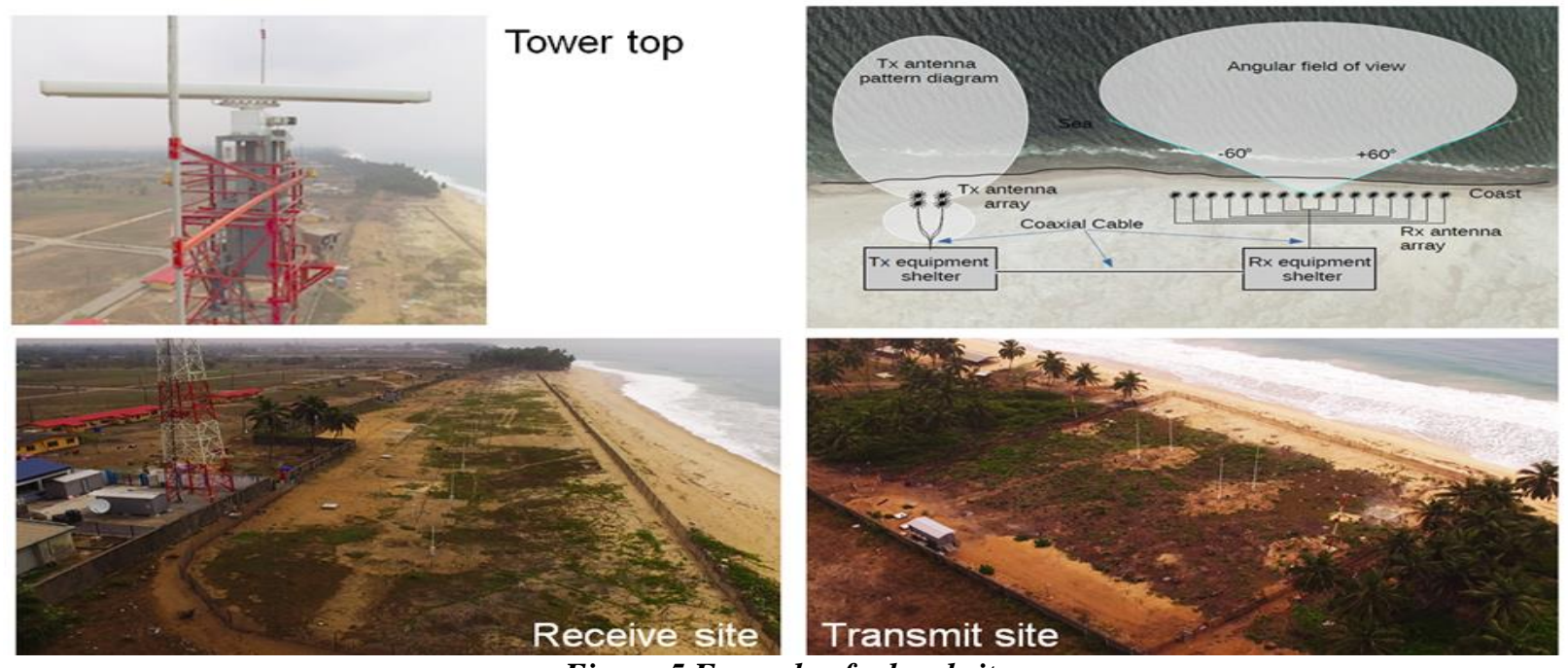

Figure 5 Example of a local site

Interaction between the incident electromagnetic wave and the ocean waves interaction is called Bragg scattering. Sea clutter is interference for ship tracking.

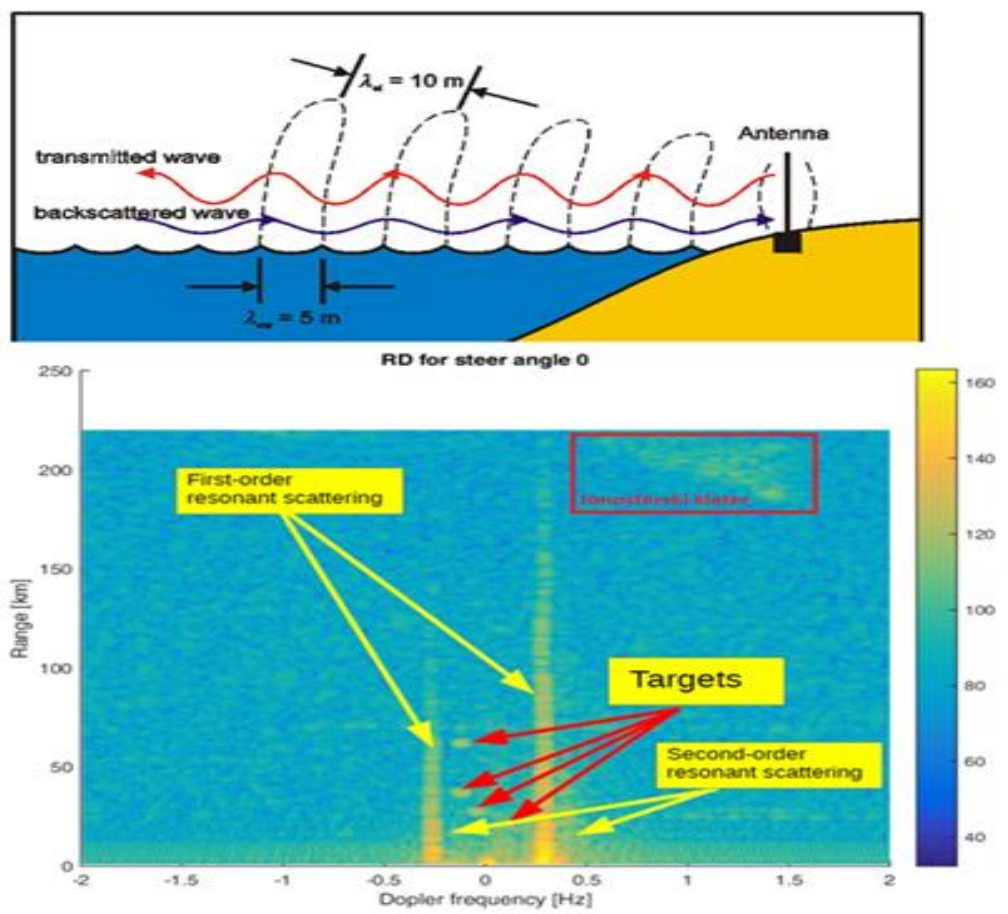

Figure 6 Sea Clutter at HF Band

\section{Network Security Key Features}

- Advanced acquisition system based on antenna array concept.

- The fast and accurate software beam-forming.

- The "quiet" and low-power (up to 4 x 1kW) non-interrupted FMCW operation mode - extremely long ranges without blind zones.

- Advanced ship detection and tracking algorithms.

- Operation in multi-frequency mode to provide highest reliability and data availability.

- $\quad$ Easy to integrate in existing and new systems

Primary application of HF-OTHR is monitoring of ships at very long distances (beyond horizon line) which is much above the range conventional microwave radars (MWR). 


\section{HF Main Propagation Effects of Network Security}

HF main propagation effects are frequency, atmospheric noise and sea state.

The most important parameter that influences radar range is frequency. The rule of thumb for HF-OTHF applies; lower frequency means higher range, but larger radar site.

The second parameter is atmospheric noise. It changes by geographic location, season and time of the day.

Losses due to the propagation distance over the sea are highly influenced by sea state. Depending of wind conditions or swell, sea states will vary.

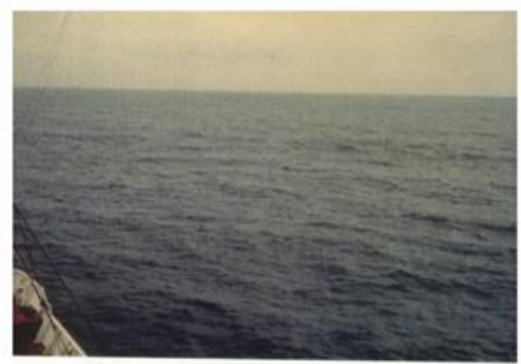

BEAUFOMT FOACE 3
WINO SPEET

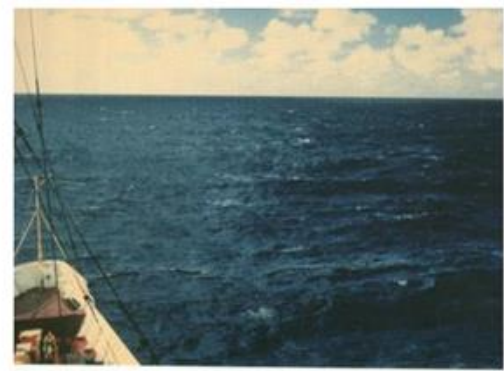

BEAUFORT FOACE S
WIND SPEED: 1721 KNOTS

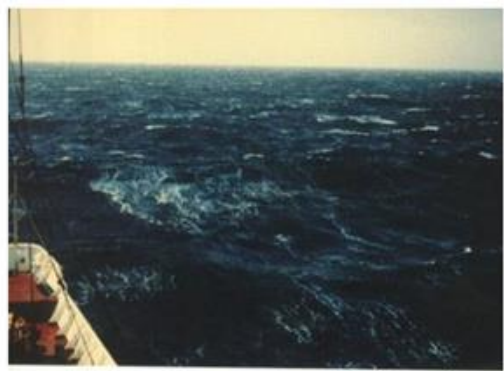

BEAUFORT FOACE 7
WINO SPEED: 28-33 KNOTS

Figure 7 HF-OTHR range performace changes in time
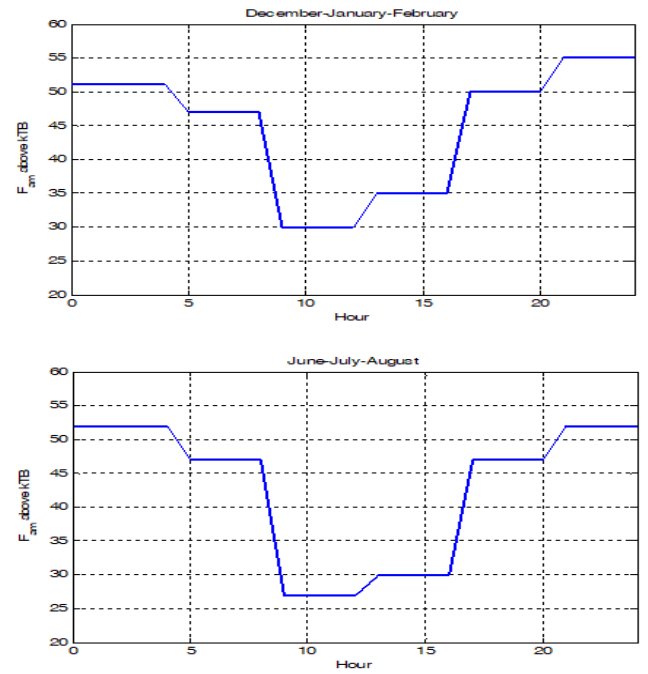
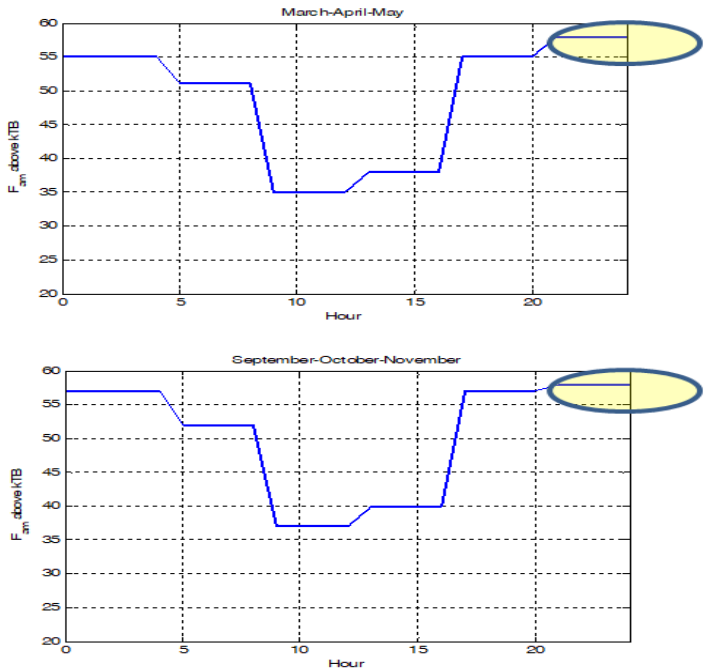

Figure 8 Radio Noise at HF band

\section{Radar Cross Section (RCS) - Trajectory Angle Influence}
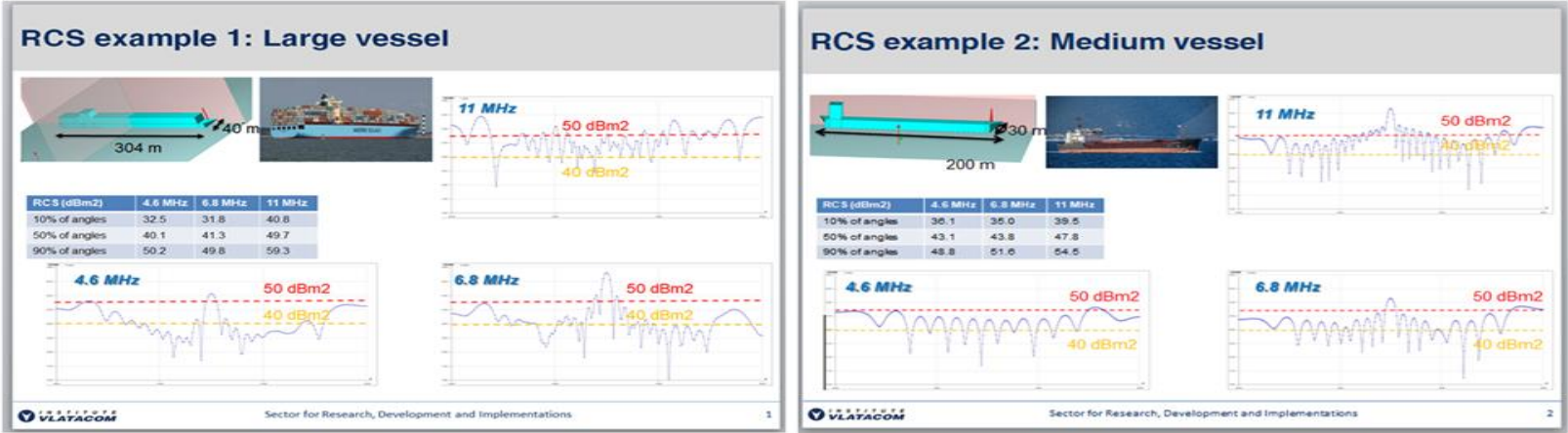

Figure 9 Radar cross section (RCS) - trajectory angle influence

Radar cross section (RCS) is parameter that defines amount of the radar signal that is reflected from target, bigger RCS means longer range. Target trajectory (angle) strongly affects RCS.

\section{RCS in HF: Unusual Behaviour and Network Security}


Larger vessel, bigger RCS is not always straight forward at HF, due to signal wavelength. For example, vertical rods make resonators at $\mathrm{HF}$ and unusually this ship has bigger RCS at $4.6 \mathrm{MHz}$ than on $11 \mathrm{MHz}$.

Lower frequency of HF-OTHR most likely will give longer range.
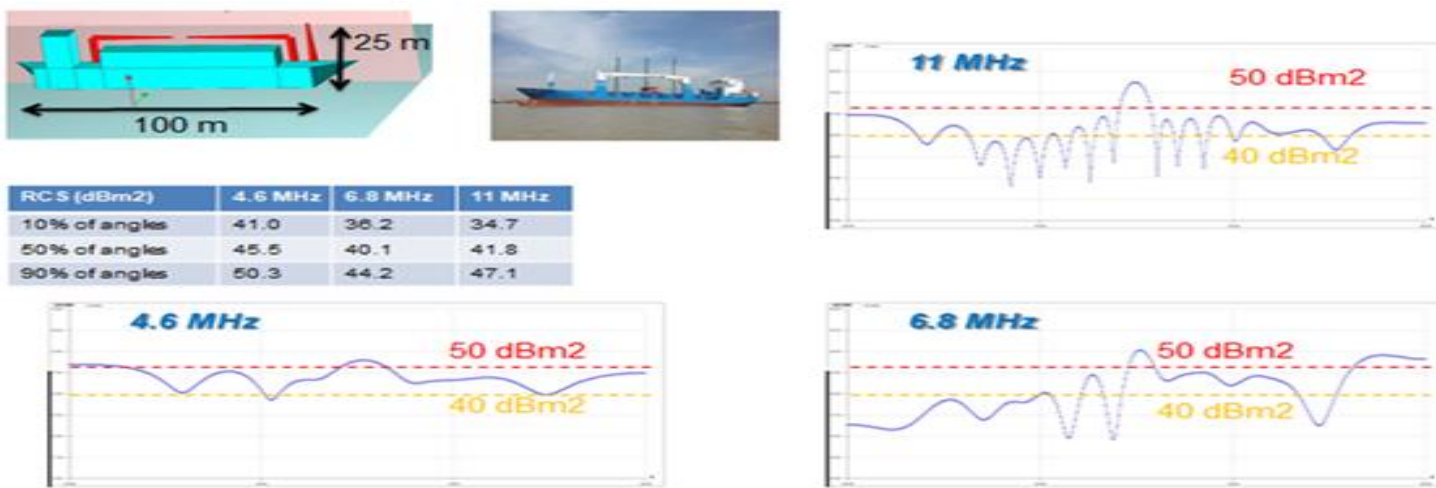

Figure 10 RCS in HF: Unusual Behaviour
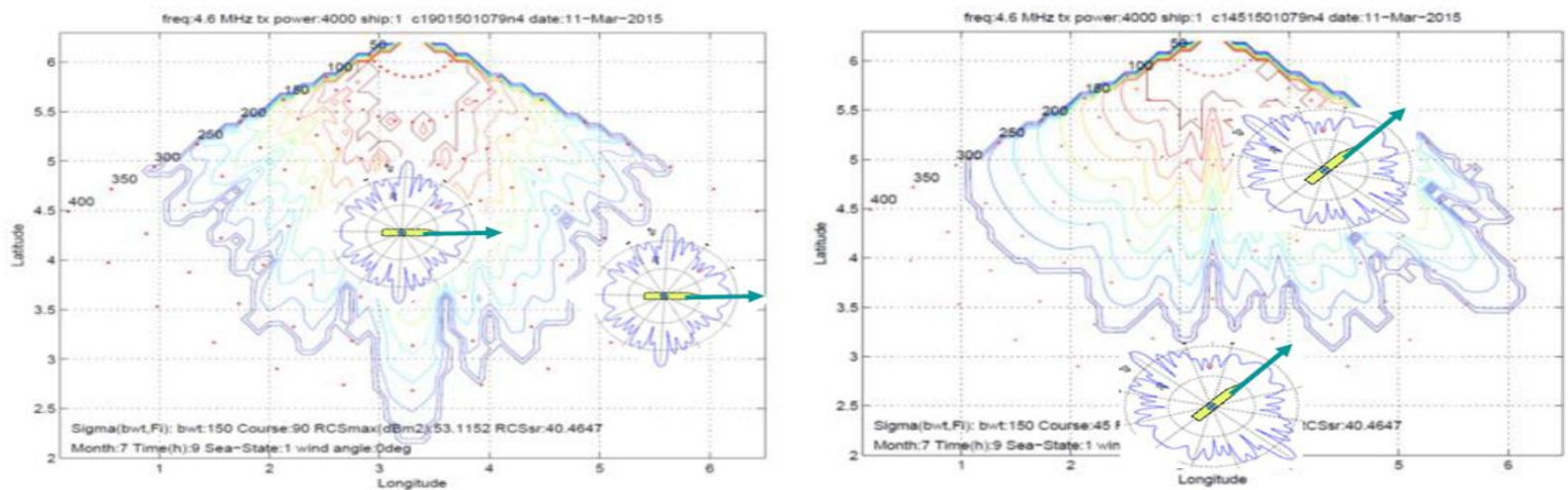

Figure 11 Radar Cross Section (ship aspect angle)

In the case where the vessel is turned broadside, detection is at a greater distance.

Performance of Network Security

Performance details for 4.0 MHz HF-OTHR are given in table below.

\begin{tabular}{|c|c|c|c|c|c|}
\hline Pos & Parameter & Description & \multicolumn{3}{|c|}{ Value } \\
\hline \multirow[t]{5}{*}{01} & \multirow{5}{*}{$\begin{array}{l}\text { Working range } \\
\text { Can be reduced } \\
\text { due to } \\
\text { environmental } \\
\text { effects }\end{array}$} & Depends on frequency & \multicolumn{3}{|c|}{ all values are valid for $4.0 \mathrm{MHz}$} \\
\hline & & for currents: & \multicolumn{3}{|c|}{$450 \mathrm{~km}$} \\
\hline & & $\begin{array}{r}\text { wind direction \& ship } \\
\text { detection: }\end{array}$ & \multicolumn{3}{|c|}{$370 \mathrm{~km}$} \\
\hline & & for wave height: & \multicolumn{3}{|c|}{$200 \mathrm{~km}$} \\
\hline & & for wave spectra: & \multicolumn{3}{|c|}{$150 \mathrm{~km}$} \\
\hline \multirow[t]{3}{*}{02} & \multirow{3}{*}{$\begin{array}{l}\text { Range resolution } \\
\text { Integration in range }\end{array}$} & $\begin{array}{|lll|}\begin{array}{l}\text { Depends } \\
\text { bandwidth }\end{array} & \text { on } & \text { allocated } \\
\end{array}$ & $30 \mathrm{kHz}$ & $50 \mathrm{kHz}$ & $100 \mathrm{kHz}$ \\
\hline & & \begin{tabular}{|l|} 
Range cell size \\
\end{tabular} & $5000 \mathrm{~m}$ & $3000 \mathrm{~m}$ & $1500 \mathrm{~m}$ \\
\hline & & $\begin{array}{c}\text { Typical target detection } \\
\text { accuracy }\end{array}$ & $1700 \mathrm{~m}$ & $1000 \mathrm{~m}$ & $500 \mathrm{~m}$ \\
\hline 03 & $\begin{array}{l}\text { Angular field of } \\
\text { view }\end{array}$ & \multicolumn{4}{|c|}{$\begin{array}{l} \pm 60^{\circ} \text { for } 16 \text { antennas in a linear array (500 } \mathrm{m} \text { long array) } \\
> \pm 70^{\circ} \text { for } 16 \text { antennas in a curved array }\end{array}$} \\
\hline 04 & Angular Accuracy & \multicolumn{4}{|c|}{$\begin{array}{l} \pm 1^{\circ} \text { for } 16 \text { antennas } \\
\pm 2^{\circ} \text { for } 16 \text { antennas in a curved array configuration } \\
\text { Typical target detection accuracy in azimuth }<1^{\circ}\end{array}$} \\
\hline \multirow[t]{4}{*}{05} & \multirow{4}{*}{$\begin{array}{l}\text { Beam width } \\
\text { Integration } \\
\text { azimuth }\end{array}$} & $\begin{array}{l}\text { depends on beam steering } \\
\text { angle }\end{array}$ & at centre & typical & at edge \\
\hline & & for 16 antennas & $\pm 3^{\circ}$ & $\pm 5^{\circ}$ & $\pm 7^{\circ}$ \\
\hline & & $\begin{array}{r}\text { for } 16 \text { antennas as curved } \\
\text { array }\end{array}$ & $\pm 4^{\circ}$ & $\pm 6^{\circ}$ & $\pm 7^{\circ}$ \\
\hline & & $\begin{array}{r}\text { angular resolution is } \\
\text { always }\end{array}$ & & $<0.1^{\circ}$ & \\
\hline
\end{tabular}

Figure 12 Performance details for 4.0 MHZ HF-OTHR

This publication is licensed under Creative Commons Attribution CC BY. 
Performance details for 6.8 MHz HF-OTHR are given in table below.

\begin{tabular}{|c|c|c|c|c|c|}
\hline Pos & Parameter & Description & \multicolumn{3}{|c|}{ Value } \\
\hline \multirow[t]{5}{*}{01} & \multirow{5}{*}{$\begin{array}{l}\text { Working range } \\
\text { Can be reduced } \\
\text { due to } \\
\text { environmental } \\
\text { effects }\end{array}$} & Depends on frequency & \multicolumn{3}{|c|}{ all values are valid for $6.8 \mathrm{MHz}$} \\
\hline & & for currents: & \multicolumn{3}{|c|}{$240 \mathrm{~km}$} \\
\hline & & $\begin{array}{r}\text { wind direction \& ship } \\
\text { detection: }\end{array}$ & \multicolumn{3}{|c|}{$170 \mathrm{~km}$} \\
\hline & & for wave height: & \multicolumn{3}{|c|}{$100 \mathrm{~km}$} \\
\hline & & for wave spectra: & \multicolumn{3}{|c|}{$80 \mathrm{~km}$} \\
\hline \multirow[t]{3}{*}{02} & \multirow{3}{*}{$\begin{array}{l}\text { Range resolution } \\
\text { Integration in range }\end{array}$} & $\begin{array}{lll}\begin{array}{l}\text { Depends } \\
\text { bandwidth }\end{array} & \text { on allocated } \\
\end{array}$ & $30 \mathrm{kHz}$ & $50 \mathrm{kHz}$ & $100 \mathrm{kHz}$ \\
\hline & & $\begin{array}{c}\text { Range cell size } \\
\end{array}$ & $5000 \mathrm{~m}$ & $3000 \mathrm{~m}$ & $1500 \mathrm{~m}$ \\
\hline & & $\begin{array}{c}\text { Typical target detection } \\
\text { accuracy }\end{array}$ & $1700 \mathrm{~m}$ & $1000 \mathrm{~m}$ & $500 \mathrm{~m}$ \\
\hline 03 & $\begin{array}{l}\text { Angular field of } \\
\text { view }\end{array}$ & \multicolumn{4}{|c|}{$\begin{array}{l} \pm 60^{\circ} \text { for } 16 \text { antennas in a linear array ( } 500 \mathrm{~m} \text { long array) } \\
> \pm 70^{\circ} \text { for } 16 \text { antennas in a curved array }\end{array}$} \\
\hline 04 & Angular Accuracy & \multicolumn{4}{|c|}{$\begin{array}{l} \pm 1^{\circ} \text { for } 16 \text { antennas } \\
\pm 2^{\circ} \text { for } 16 \text { antennas in a curved array configuration } \\
\text { Typical target detection accuracy in azimuth }<1^{\circ}\end{array}$} \\
\hline \multirow[t]{4}{*}{05} & \multirow{4}{*}{$\begin{array}{l}\text { Beam width } \\
\text { Integration } \\
\text { azimuth }\end{array}$} & $\begin{array}{l}\text { depends on beam steering } \\
\text { angle }\end{array}$ & at centre & typical & at edge \\
\hline & & for 16 antennas & $\pm 3^{\circ}$ & $\pm 5^{\circ}$ & $\pm 7^{\circ}$ \\
\hline & & $\begin{array}{r}\text { for } 16 \text { antennas as curved } \\
\text { array }\end{array}$ & $\pm 4^{\circ}$ & $\pm 6^{\circ}$ & $\pm 7^{\circ}$ \\
\hline & & $\begin{array}{r}\text { angular resolution is } \\
\text { always }\end{array}$ & & $<0.1^{\circ}$ & \\
\hline
\end{tabular}

Figure 13Performance details for 6.8 MHZ HF-OTHR

\section{HF-OTHR Hardware and Antennas}

\section{Hardware}

Hardware subsystem of proposed solution includes:

- vHF-OTHR dedicated hardware,

- $\quad$ standard IT hardware, and

- $\quad$ system-specific Power amplifier components.

vHF-OTHR Dedicated Hardware

vHF-OTHR dedicated hardware is consist of User Interface PC, Power Supply Rack, Receiver Racks and Frequency Control Rack.

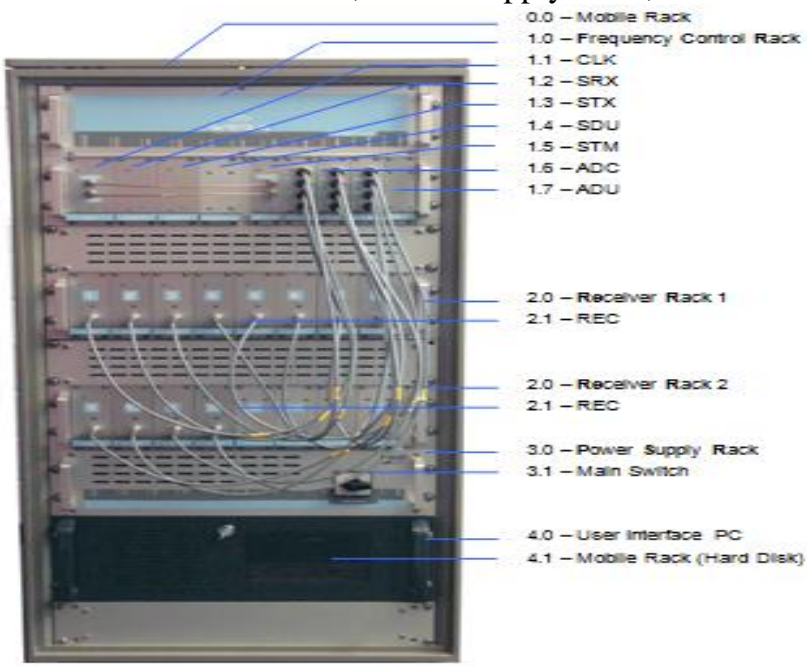

Figure 14 Front view example, vHF-OTHR 12-Channel System

\section{FCR - Frequency Control Rack}

The FCR purpose is to generate required signals and provides Tx and Lo signals. Also it have state machine (process control unit STM) and the ADCs. 


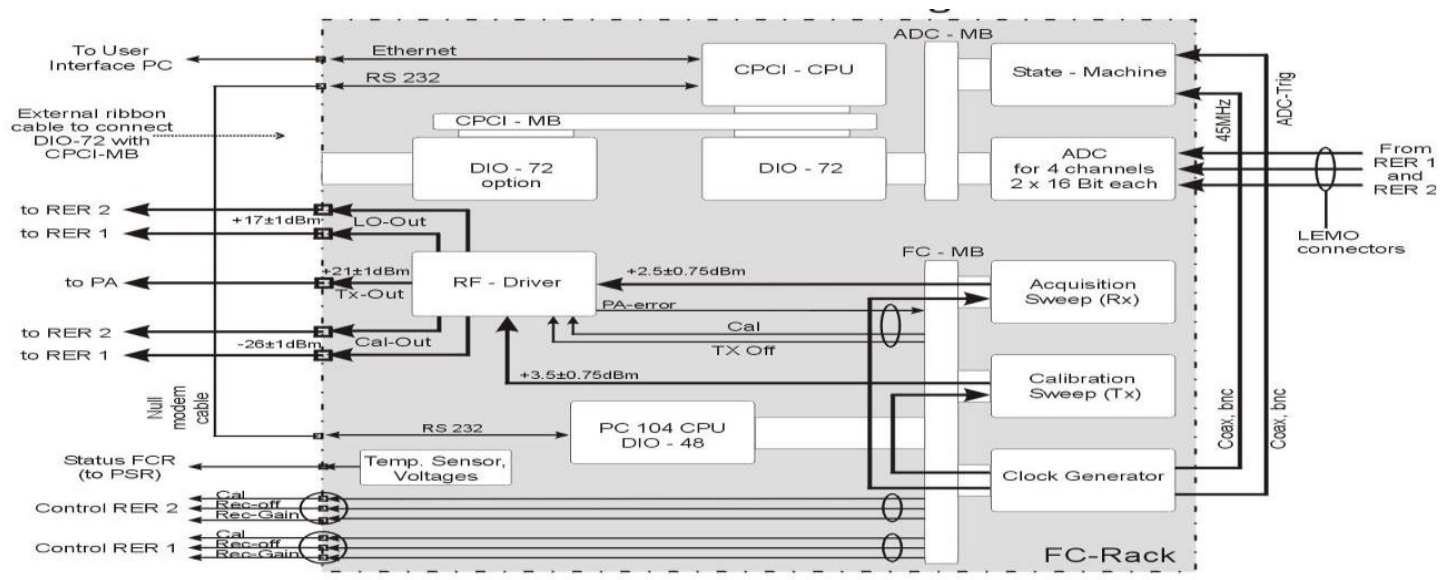

Figure 15 FCR Block Diagram

It holds the following main modules, CLK, STX, SRX, SDU, STM, ADC, RTU, CTU:

- Clock - CLK - This is the master clock for the whole vHF-OTHR system. The standard module has got one clock and trigger output only. The third connector is for the GPS antenna, to be used only with the GPS clock version.

- $\quad$ Sweep-RX - SRX / Sweep-TX - STX / Sweep Dummy - SDU - The sweep modules generate the transmit (TX) and receive (RX) signals for the measurement. Normally their output is a linearly swept frequency sweep. The Rx sweep is active during acquisition. The Tx is used for calibration only and can be used as a "spare part" in case of a failure of the Rx sweep. The sweep dummy is an empty housing in an unused sweep module slot of the FCR. Its purpose is to keep the correct airflow and thus the proper cooling of the other modules.

- $\quad$ State-Machine - STM - The state machine synchronises data acquisition.

- A/D converter - ADC - Each ADC module samples I and Q information of four receive channels.

- $\quad$ RTU - Real-Time-Unit - The real time unit controls data acquisition and stores measurement data on the user interface pc. It communicates with the user interface pc and forwards all needed parameters to the control unit. RTU is based on CPCI computer, with dedicated software package.

- CTU - Control-Unit - The control unit is based on PC104. This unit programs the sweep modules with the parameters received from the real time unit and controls the receive and transmit signals.

RER - Receiver Rack

RER holds input filters and 8 channels receiver modules.

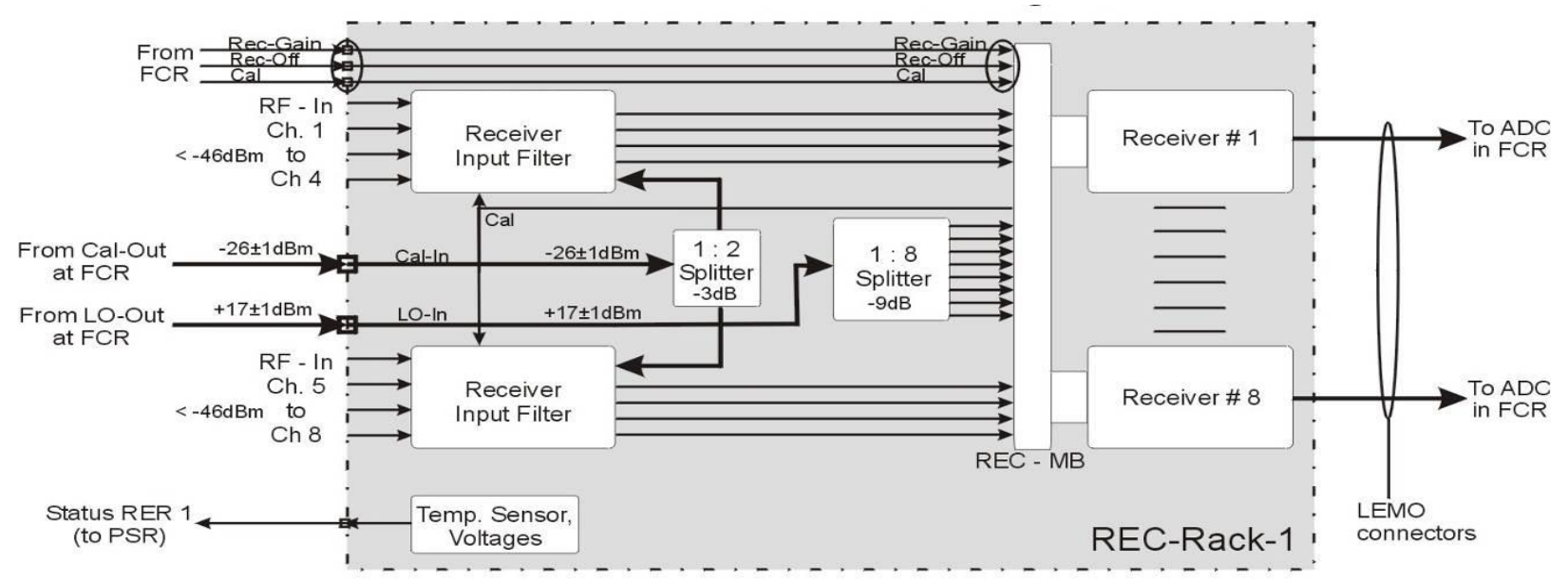

Figure 16 RER Block Diagram

\section{PSR - Power Supply Rack}

The PSR is used to remotely switch on and off individual parts of the system, e.g. to save power at sites that produce their own energy.

Furthermore it monitors the temperatures and voltages inside the racks.

Additionally it can be used to remotely control the output power of a rack mounted power amplifier. 


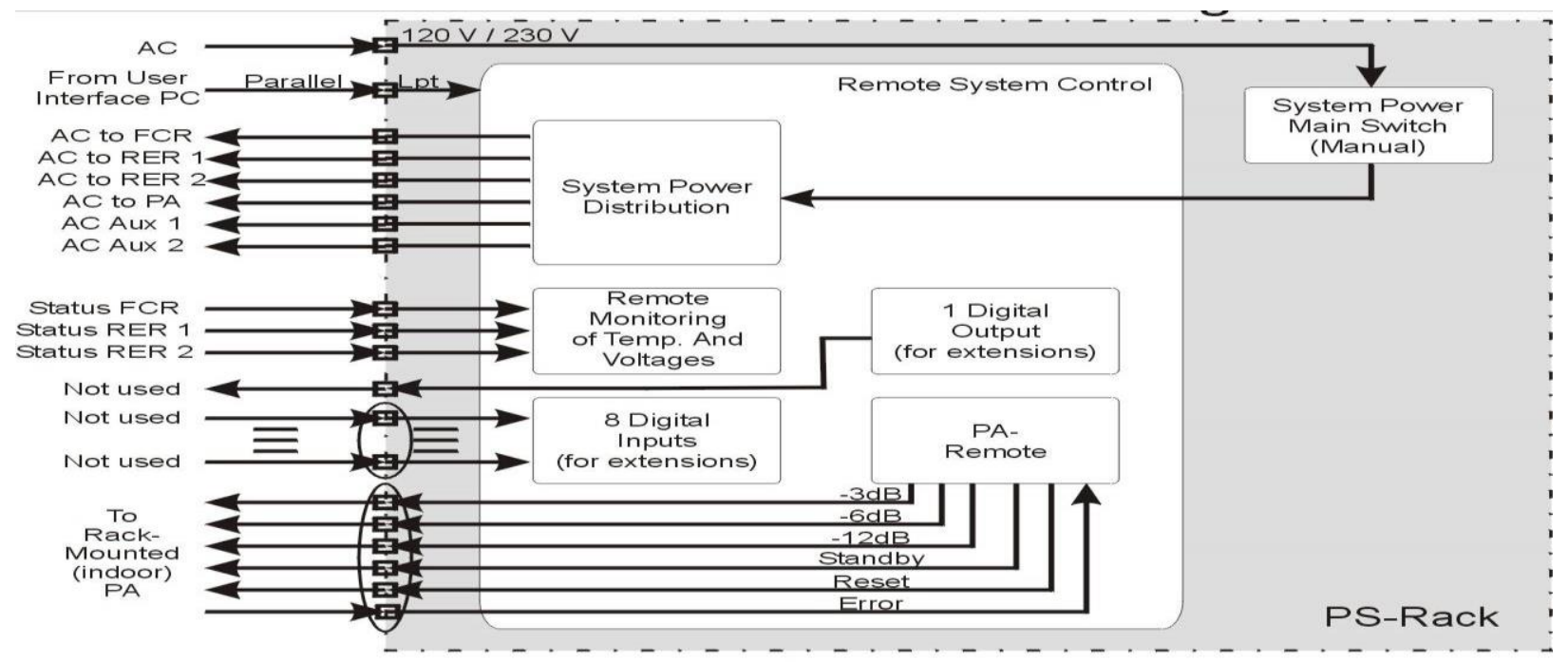

Figure 17 PSR Block Diagram

\section{PA - Power Amplifier}

The standard version of the power amplifier is housed in 19" rack, $3 \mathrm{HU}$. This version can provide up to 1.000 Watts output power to compensate cable loss. The antennas could be connected via an external 1:4 power splitter with two pairs of "phase cables": the longer cables are always used to connect those antennas which are located closer to the water front, or each antenna can be powered by particular amplifier.

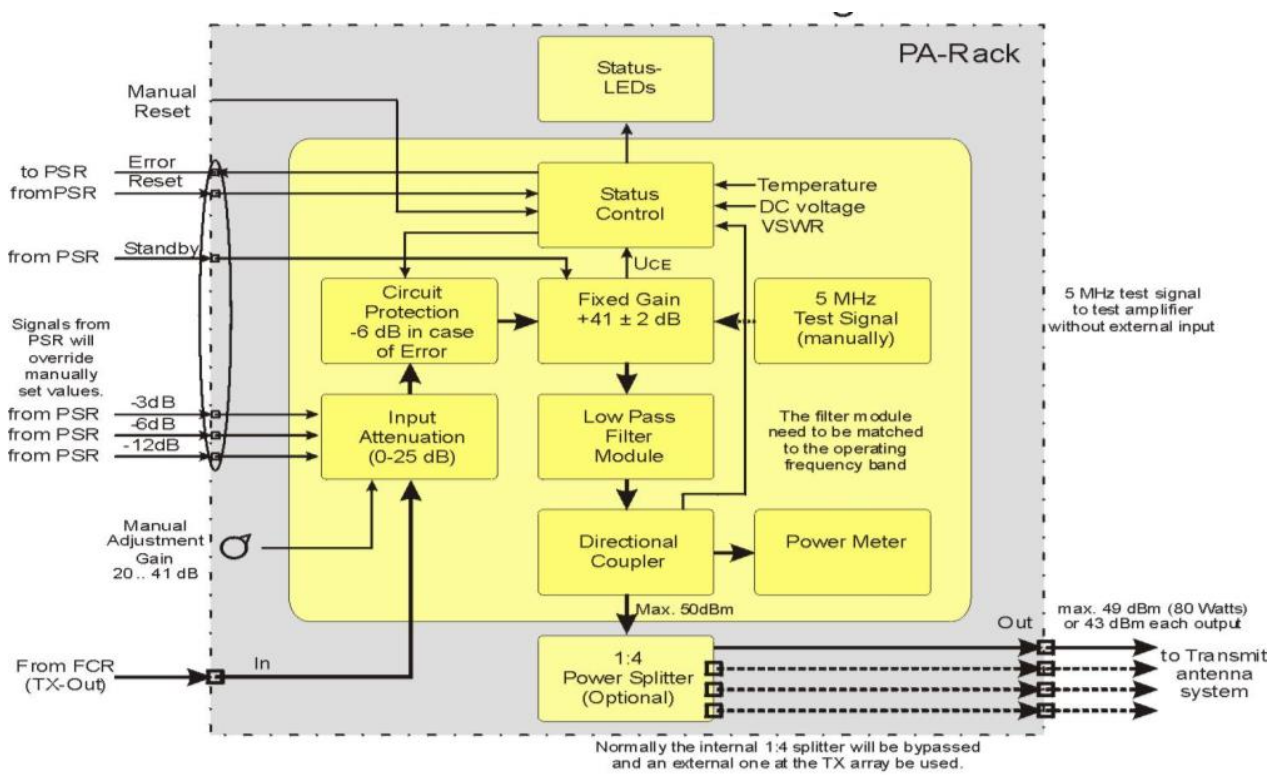

Figure 18 Power Amplifier - Block Diagram

\section{IPC - User-Interface-PC}

The User Interface PC is used to control the system. Measured data are stored on removable hard disks and can also be sent to a central processing station over a data link. There are tools to process and visualize the data.

\section{Block Diagram of Interconnecting Cables}



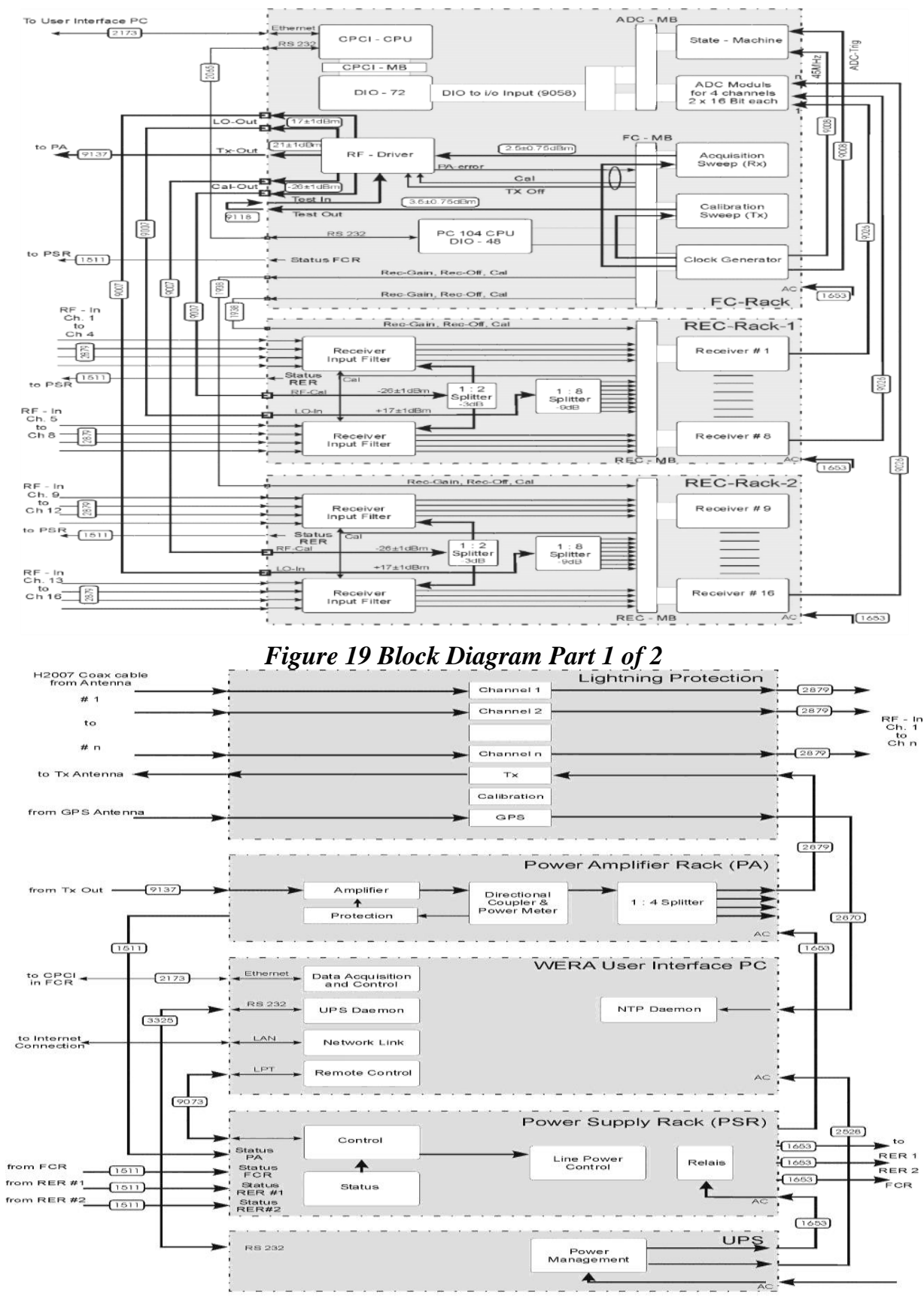

Figure 20 Block Diagram Part 2 of 2

\section{Transmitting Antenna Array Design Considerations and Network Security}

Transmitting antenna array is designed to have maximum radiation in sea direction, while the minimum in radiation pattern is directed towards the receiving antenna array. Array consists of four monopole antennae in rectangular layout, shown on Figure . 


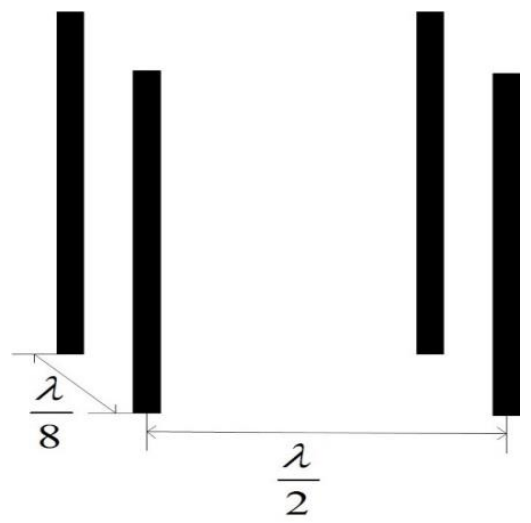

Figure 21 Structure of transmitting antenna array Antenna pattern in horizontal plane is presented on Figure .

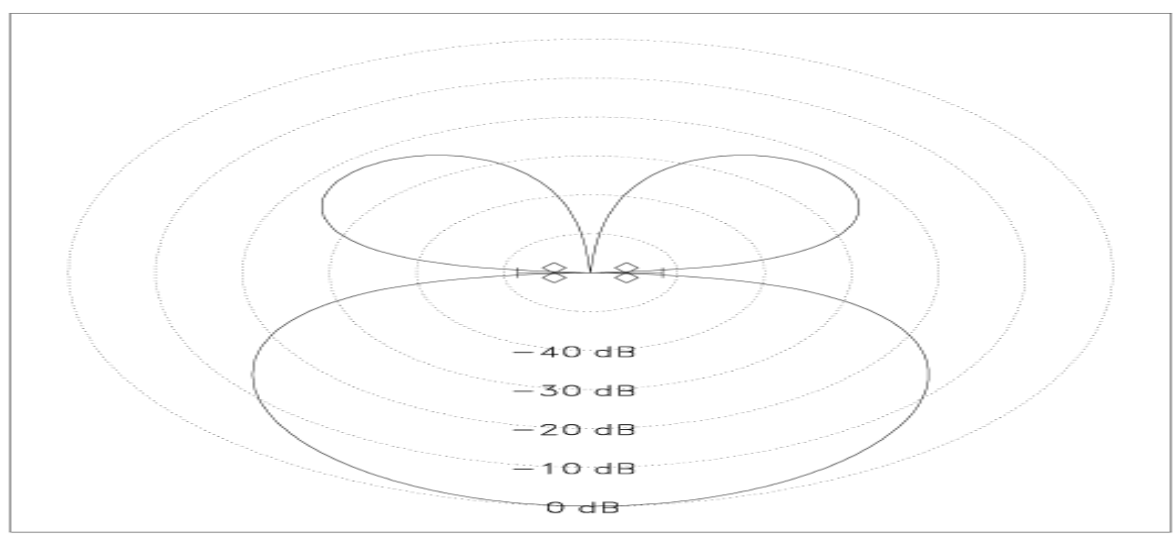

Figure 22 Antenna pattern of transmitting array

Antenna setup for configuration where all Tx antennas are powered from single power amplifier is presented in Figure .

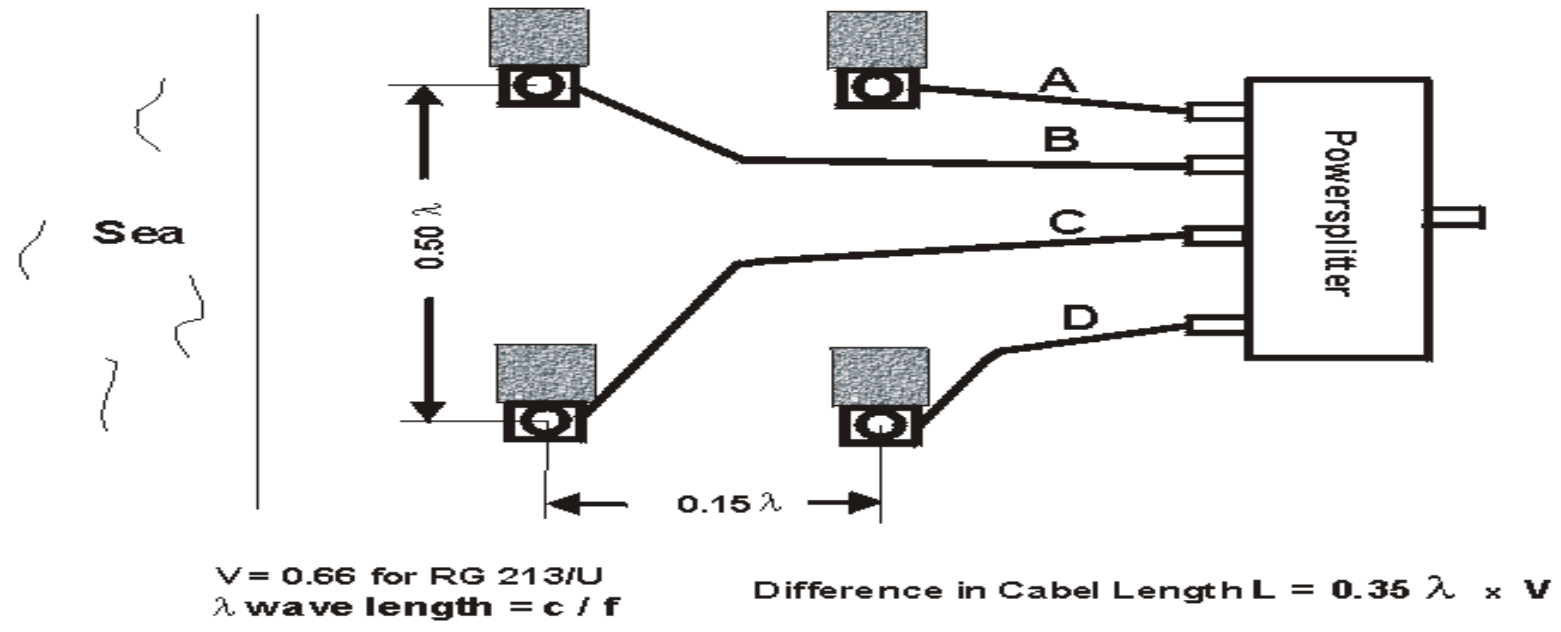

Figure 23 Tx antenna setup

As alternative to presented approach, every Tx antenna could be fed by particular power amplifier: the selection directly depends on maximum value of radiated power defined per single antenna element.

\section{Transmit Power and Frequency Considerations in Network security}

The first factor in definition of expected performance of particular vHF-OTHR system is its operating frequency: due to physical dependence of surface waves range from ambient attenuation at seaside, these values can vary over HF range at day and night time. Some basic limitations in discussed manner are presented in Figure . 


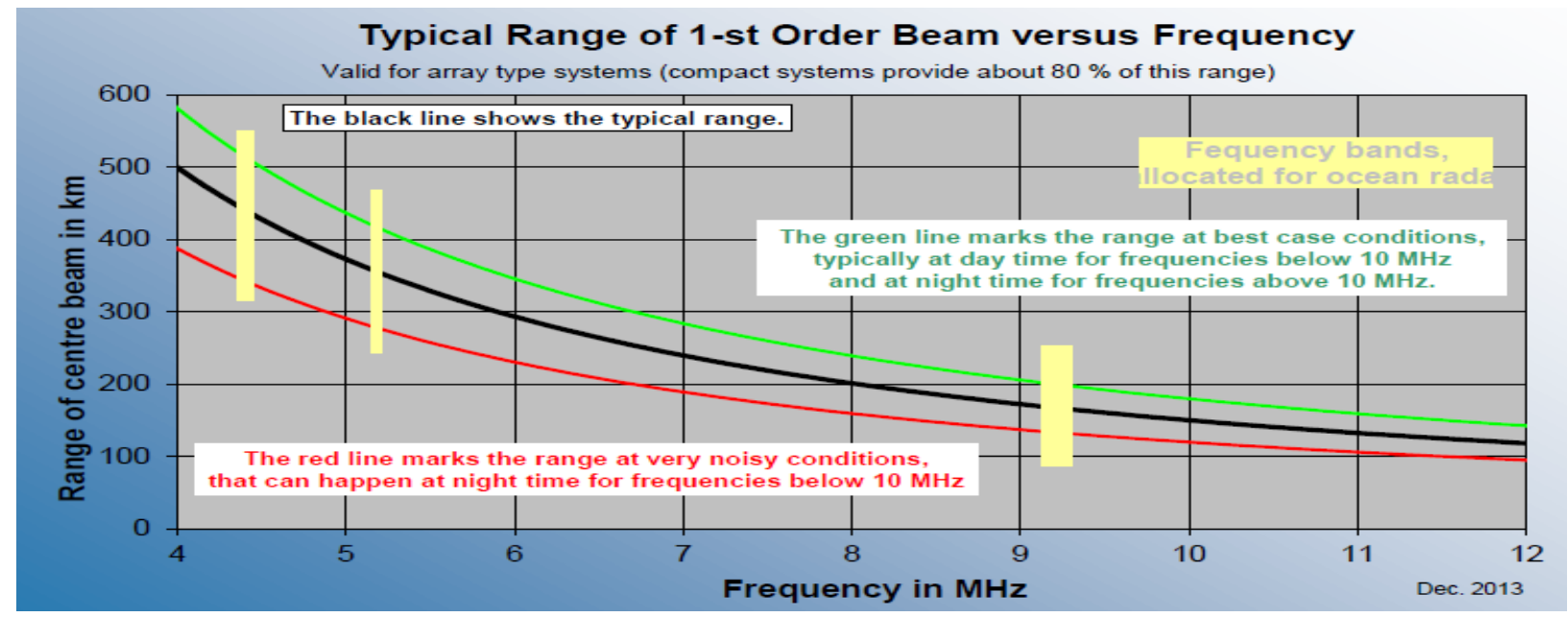

Figure $24 \mathrm{HF}$ signal range fluctuation due to ambient noise

Figure shows that strong fluctuation in range is present even in conditions which are perfect for propagation. Also, selected frequency directly defines the basic dimension of a target that can be detected: this value is directly proportional with wavelength of the system.

Based on environment attenuation, maximum ranges for example ship target are summarized in following table:

Table 1 Maximum range in detection of $200 \mathrm{~m}$ ship, depending on radar frequency and day/night variation
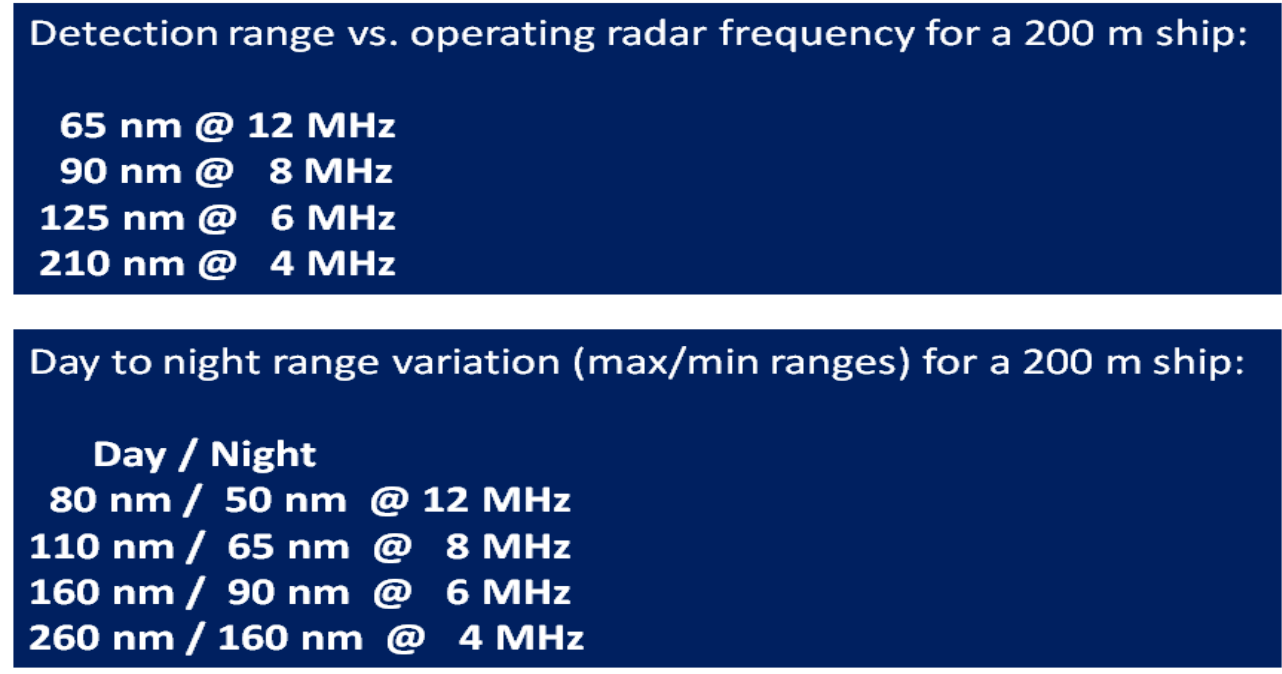

Achievement of presented maximum range (at any frequency) requires necessary output power of a radar. While for ranges going up to $100 \mathrm{~nm}$ this power is at order of magnitude $\sim 100 \mathrm{~W}$, for higher ranges required output power goes to higher order of magnitude $\sim 1000 \mathrm{~W}$.

System power is calculated for specific project, depending on required range, operating frequency, sites locations and propagation conditions.

System performance is highly dependent on sea conditions: maximum range values, calculated under perfect conditions and presented in Table 1, are shown in dependence from Sea State conditions in Figure . 


\section{Depending on ship size and operation conditions, in comparison with ranges previously listed:}

\begin{tabular}{|c|c|c|c|}
\hline \multicolumn{4}{|c|}{ Range vs. ship size and sea state, normalized to the range for a large vessel at Sea State $3(=100 \%)$} \\
\hline Large vessel & Medium vessel & Small vessel & Very small vessel $<80 \mathrm{~m}$ \\
\hline DWT $60,000-150,000$ & DWT $10,000-50,000$ & DWT $5,000-10,000$ & 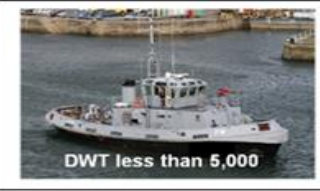 \\
\hline Sea State 3: $100 \%$ & Sea State 3: $90 \%$ & Sea State 3: $85 \%$ & Sea State 3: $75 \%$ \\
\hline Sea State 5: $100 \%$ & Sea State 5: $90 \%$ & Sea State 5: $80 \%$ & Sea State 5: $50 \%$ \\
\hline Sae State 7: $90 \%$ & Sae State 7: $80 \%$ & Sae State 7: $70 \%$ & Sae State 7: $30 \%$ \\
\hline
\end{tabular}

Figure 25 Relative value of maximum range, depending on Sea State conditions

Finally, achieved range and - especially - achieved accuracy in azimuth, is directly dependent from the number of antennas present in Rx array. This dependence is summarized in Table 2 for one example operating frequency.

Table 2 Range and azimuth accuracy depending on number of Rx antennas Technical Specification for $4 \mathrm{MHz}$

\begin{tabular}{|c|c|c|c|c|c|c|}
\hline $\begin{array}{c}\text { System } \\
\text { Type } \\
\text { Number } \\
\text { of } \\
\text { antennas }\end{array}$ & $\begin{array}{l}\text { Range } \\
\text { for Bragg } \\
\text { Lines }\end{array}$ & $\begin{array}{l}\text { Range } \\
\text { for vessel } \\
\text { tracking }\end{array}$ & $\begin{array}{l}\text { Accuracy } \\
\text { in range } \\
\text { direction } \\
\text { @ } 100 \mathrm{kHz} \\
\text { bandwidth }\end{array}$ & $\begin{array}{l}\text { Accuracy } \\
\text { in azimuth } \\
\text { @ } 100 \mathrm{~km} \\
\text { distance }\end{array}$ & $\begin{array}{l}\begin{array}{c}\text { Accuracy } \\
\text { in azimuth }\end{array} \\
\text { @ } 200 \mathrm{~km} \\
\text { distance }\end{array}$ & $\begin{array}{c}\text { Accuracy } \\
\text { in azimuth } \\
\text { @ } 400 \mathrm{~km} \\
\text { distance }\end{array}$ \\
\hline 16 & $640 \mathrm{~km}$ & $450 \mathrm{~km}$ & $1.5 \mathrm{~km}$ & $1,6 \mathrm{~km}$ & $3,2 \mathrm{~km}$ & $6,4 \mathrm{~km}$ \\
\hline 12 & $630 \mathrm{~km}$ & $400 \mathrm{~km}$ & $1.5 \mathrm{~km}$ & $2,4 \mathrm{~km}$ & $4,8 \mathrm{~km}$ & $9,6 \mathrm{~km}$ \\
\hline 8 & $570 \mathrm{~km}$ & $350 \mathrm{~km}$ & $1.5 \mathrm{~km}$ & $4,4 \mathrm{~km}$ & $8,8 \mathrm{~km}$ & $17,6 \mathrm{~km}$ \\
\hline 4 & $500 \mathrm{~km}$ & $200 \mathrm{~km}$ & $1.5 \mathrm{~km}$ & $17,5 \mathrm{~km}$ & $35 \mathrm{~km}$ & $70 \mathrm{~km}$ \\
\hline
\end{tabular}

In order to provide the best performance, 16 antenna $\mathrm{Rx}$ array is selected for implementation in proposed project. Range resolution is defined by selected bandwidth. This dependence is presented in Figure 1.

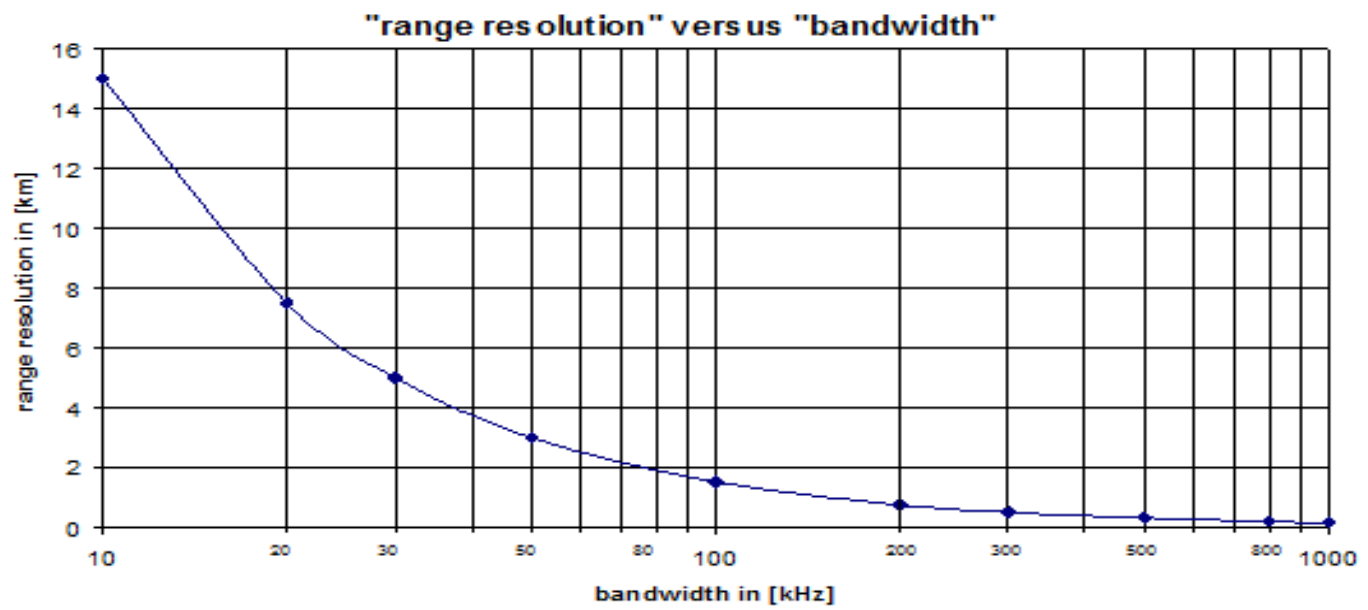

Figure 1 Range resolution in dependence from system bandwidth 


\section{EM Radiation and Safety and Network Security}

Transmitting power is generated via $4 \mathrm{Tx}$ antennas, where upper limit value per antenna is $1 \mathrm{~kW}$. Wavelength is calculated from operating frequency of Tx array (of the system). Gain of Tx antennas is 1.46 (1.66 dBi). Upper limit value for total power radiated by the Tx antenna network is $4 \mathrm{~kW}$. Strength of electric field is calculated according formula:

$$
E=\frac{\sqrt{30 P G}}{R}
$$

where $P$ is power (W), $G$ is gain and $R$ (in meters) distance from the antenna.

\section{Ship Detection and Tracking}

HF-OTHR system is made according to following schematics.

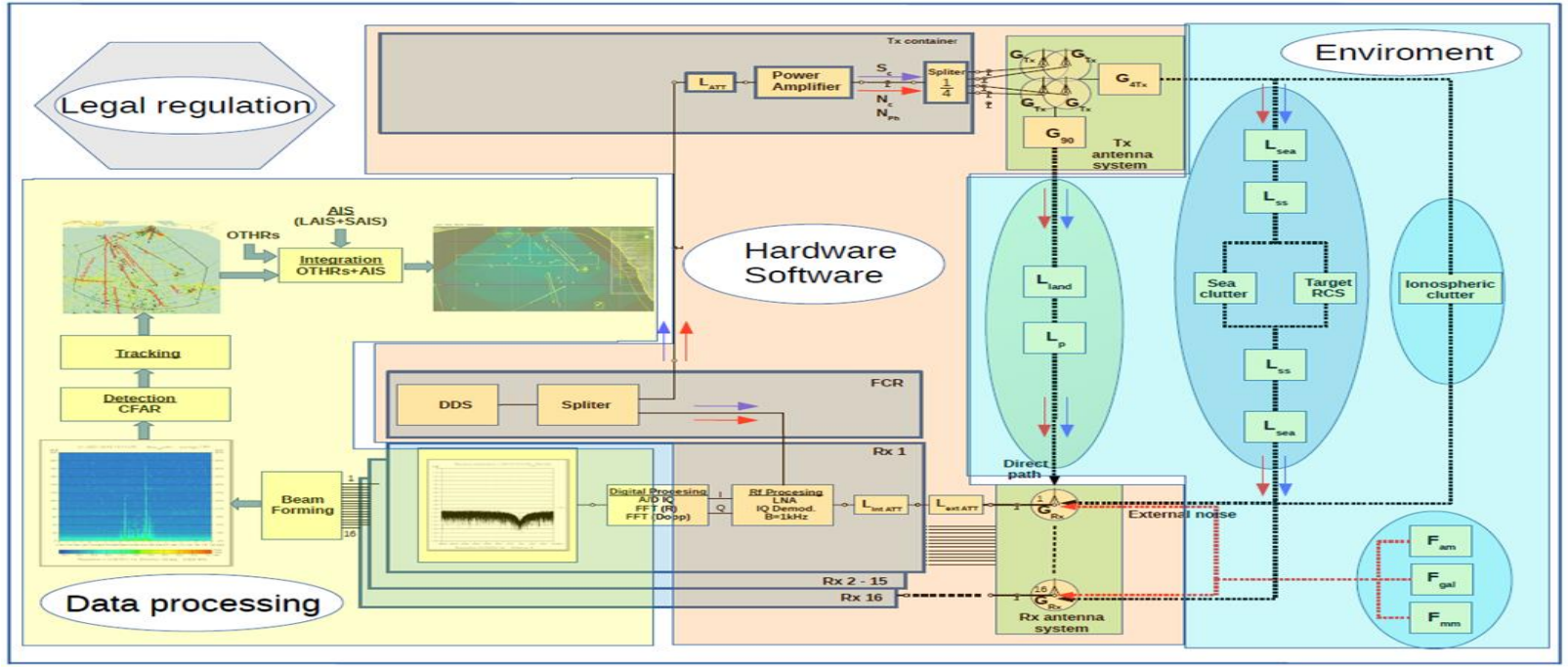

Figure 27 HF-OTHR system

Signal processing is done according to following schematics.

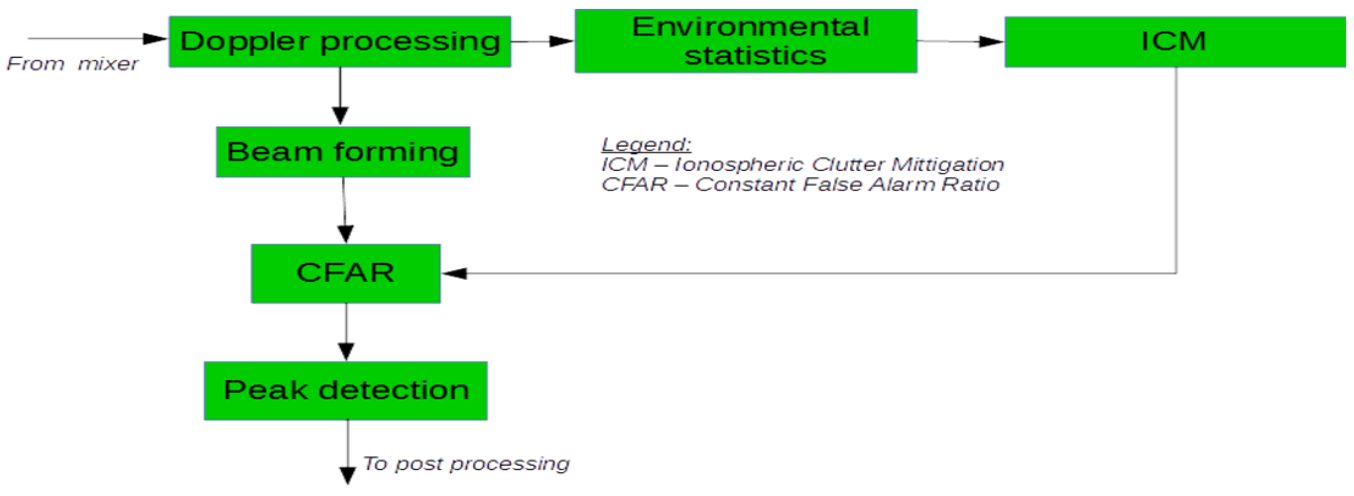

Figure 28 Signal Processing 


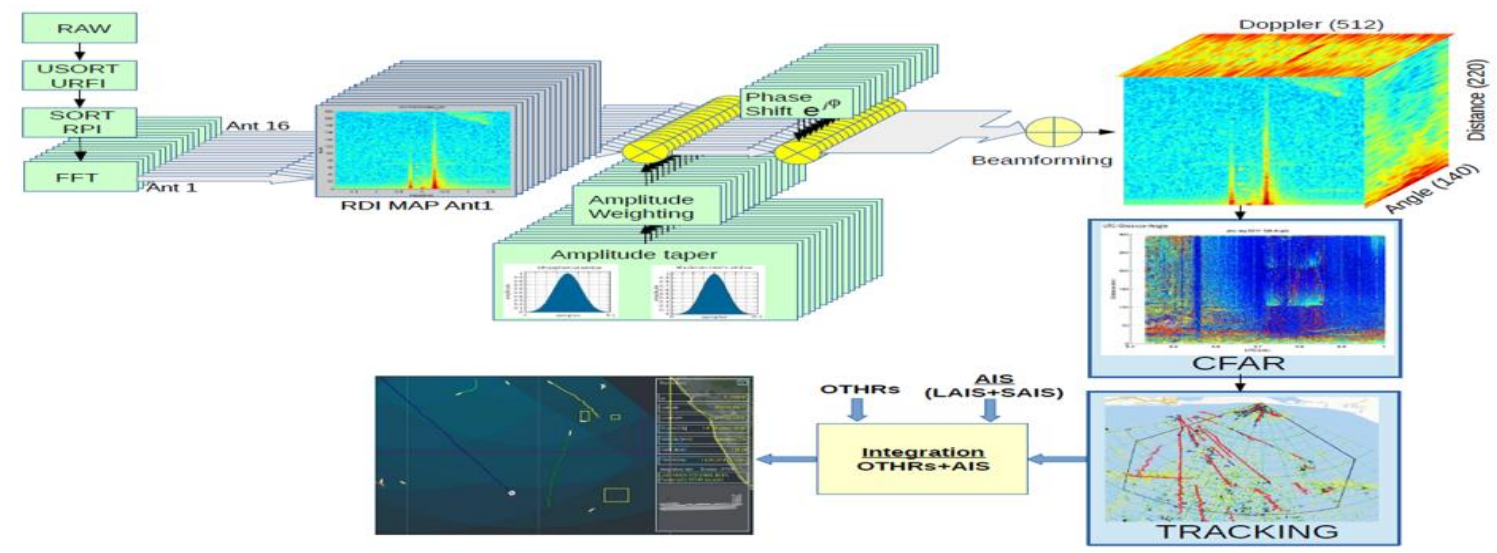

Figure 29 Signal Processing

HF-OTHR has the option of target tracking, allowing for simpler signal processing and enabling prediction of target movement. Previous tracks are also stored allowing visualization of trajectories over a large time span. Complex algorithms and models are used for tracking.

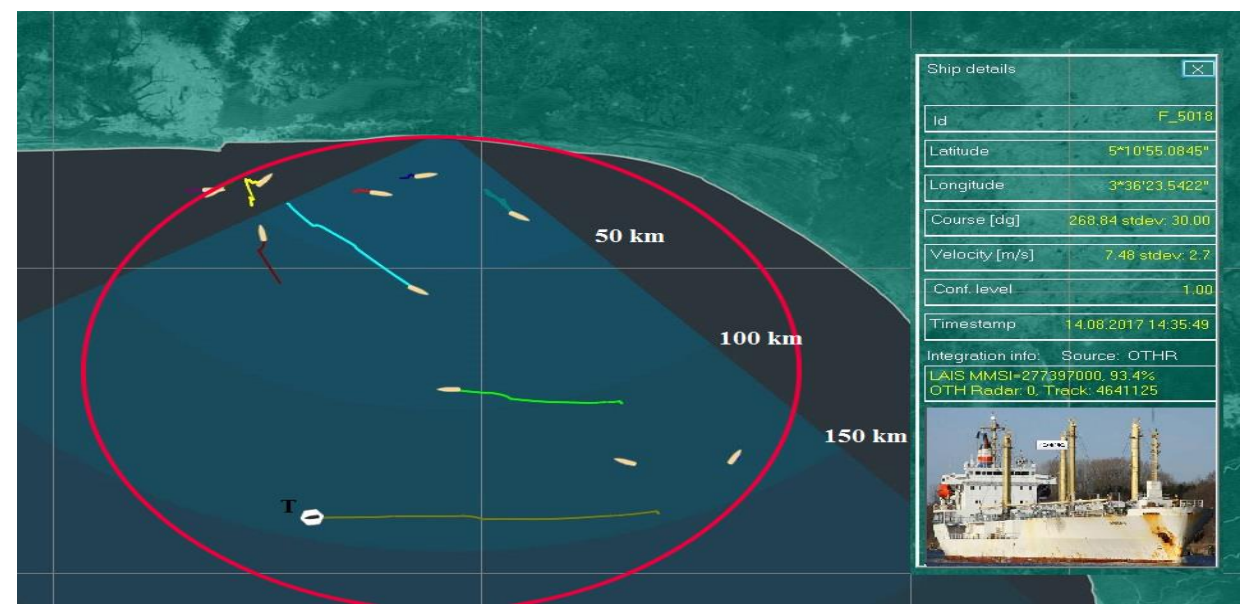

Figure 30 HF-OTHR Tracking

\section{Long Coastline Coverage by Overlapping OTHRs}

Combination of several OTHR systems is made, 120 degrees in coverage each, in order to provide global coverage.

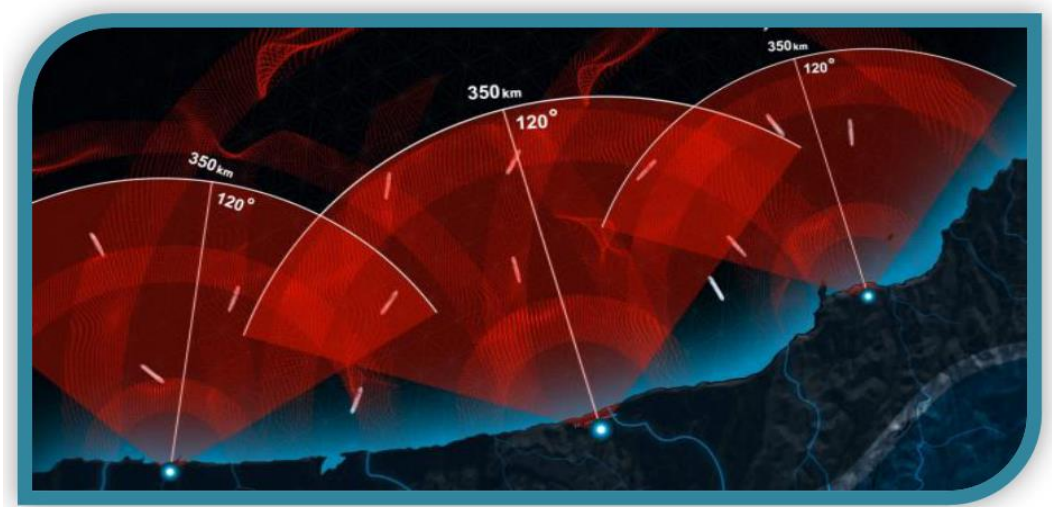

Figure 31 Long Coastline Coverage by Overlapping OTHRs

\section{Data network security in $\mathrm{HF}$-OTHRs}

For the purpose of improved coverage a network of multiple HF-OTHRs can be deployed. Coverage areas of these systems partially overlap, as shown in the picture below. In areas covered by more than one HF-OTHR an algorithm will correlate targets from multiple radar systems that are probable to represent the same vessel. This approach allows confirmation of vessel detection and continuation of tracking even if one of the radars stops detecting the vessel. 


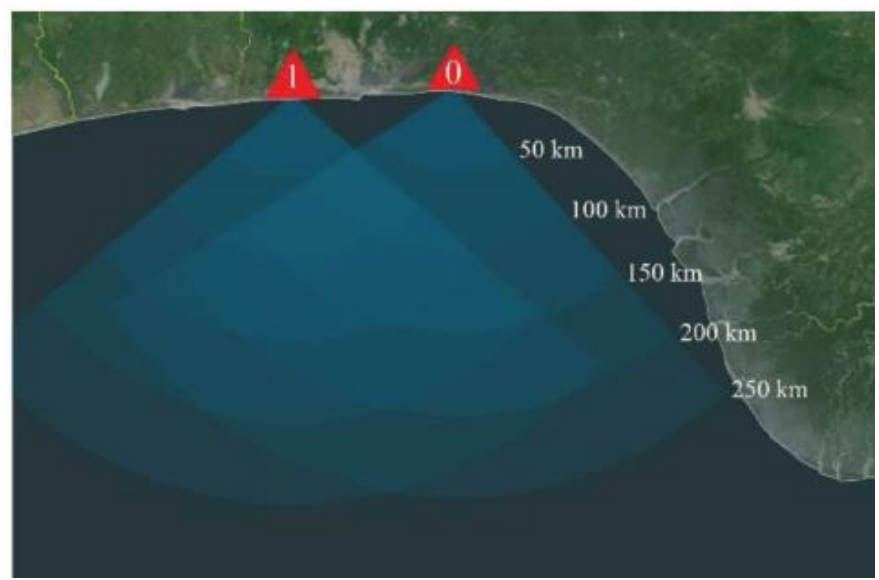

Figure 32 Data Fusion From Multiple HF-OTHRs

\section{Data Integration Algorithm in Network Security}

This approach is already implemented in operating systems, and is showing excellent results in practice. Redundance in radar coverage ensures that tracking is more stable than in the case of a single radar coverage. Integration of data with AIS makes it easier to discern potentially illegal activities, during which the perpetrators might turn the AIS transponder off.Image below shows the ability of HF-OTHR to correlate tracks with AIS data.

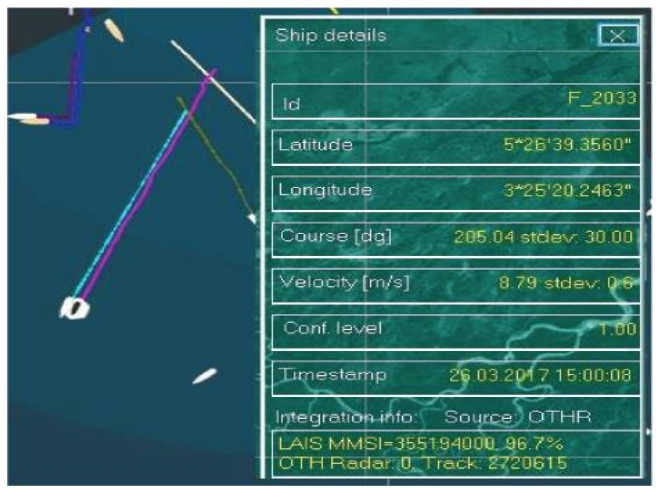

Figure 33 Data integration algorithm

\section{Improving Network Security in OTHR output: Target Tracks}

Vessel tracks are very clear and noninterrupted even in poor weather conditions. Multiple OTHR are efficiently utilized to eliminate blind zones. Unwanted propagation effects (e.g. ionosphere clutter/interference) influence is removed. User friendly interface give the operator accurate information about detected objects and possible alarms regarding its behavior.

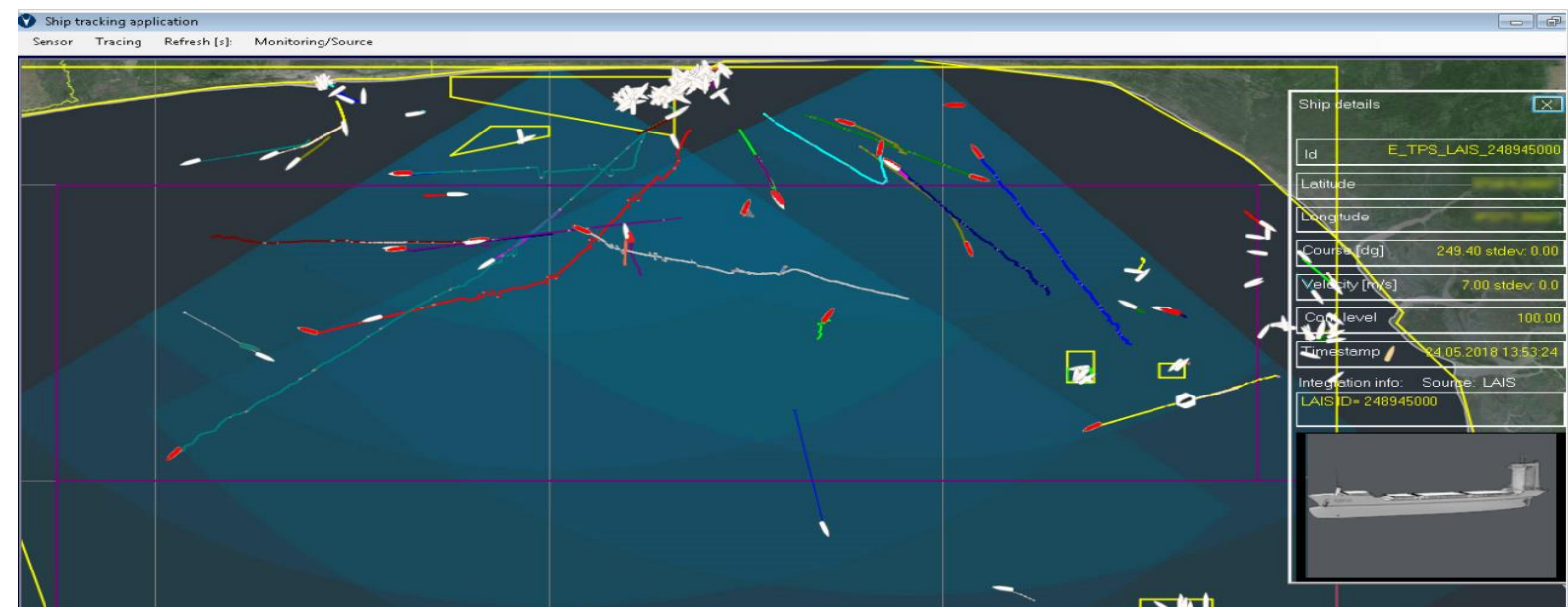

Figure 34 OTHR output: target tracks 


\section{Advanced Tracking and System Integration}

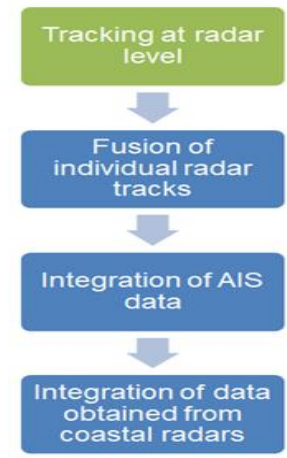

Stages of post processing:

\section{Figure 35 Advanced tracking and system integration}

- $\quad$ Each vHF-OTHR creates its own tracks

- At $\mathrm{C} 2$ level all tracks are fused and combined in order to provide unique tracks

- Available AIS data (both LAIS and SAIS) are assigned to corresponding OTHR tracks

- In order to provide complete operational picture data available from coastal radars must be integrated

4 Conclusion

For the detailed site planning it is required to inspect the site and investigate carefully the local conditions.

The vHF-OTHR site geometry is most important. The best option is to get the Tx in-line with the Rx array.

The distance should always be $>100 \mathrm{~m}$, depending on operating frequency and power. For long range systems it is important to know, that every additional meter will give more range. The optimum is calculated on the basis of system parameters and spatial conditions on site.

The distance between Tx array and the Tx electronics in container should be taken into account. It is preferred to keep this distance low enough to provide sufficient radiation power, in comparison with power cable length and its attenuation.

If there is no chance to place the $\mathrm{Tx}$ in-line with the $\mathrm{Rx}$, other options are:

- Place Tx above or below the Rx level, e.g. at least $10 \mathrm{~m}$ above but not direct behind the Rx array, or down hills at a cliff.

- Another option is to place the Tx slightly in-front of the Rx array but of course in a predefined distance aside.

No option is to place the Tx behind the Rx array.

Even when official approval for operating frequency is awarded by authorities, spectrum scanning if performed at site survey for convenience.

\section{REFERENCES}

[1] S. Haykin, S., and H.C. Chan, 'Computer simulation study of a radar Doppler processor using the maximum-entropy method', IEE Proceedings F - Communications, Radar and Signal Pro-cessing, Vol. 127, (6), pp. 464-470, 1980.

[2] J. Klostermeyer, 'Maximum entropy estimation of Doppler shift and spectral width of VHF ra-dar signal', Radio Science, Vol. 24, (1), pp. 47-63, 1989.

[3] D. Parsons, "Mobile radio propagation channel", 2nd edition, Wiley, 2000.

[4] H.T. Friis, "A note on a simple transmission formula", Proc. IRE, Vol. 34, pp.254-6, 1946.

[5] S. Rotheram, "Ground-wave propagation. Part 1: Theory for short distances", IEE Proc. Part F, Communications, Volume: Vol. 128, Issue: 5 , pp. 275 - 284, October 1981.

[6] S. Rotheram, "Ground-wave propagation. Part 2: Theory for medium and long distances and reference propagation curves", IEE Proc. Part F, Communications, Volume: Vol. 128, Issue: 5 , pp. 285 - 295, October 1981.

[7] D. Barrick, "First-order theory and analysis of MF/HF/VHF scatter from the sea", IEEE Trans. Ant. and Prop., vol. AP-20, pp. 2-10, January 1972.

[8] K.-W. Gurgel, H.-H. Essen, T. Schlick, "The University of Hamburg WERA HF radar- theory and solutions", Proc. of the 1st International Radiowave Oceanography Workshop ROW-2001, Oregon, USA, pp.19-25, April 2001.

[9] A. Dzvonkovskaya, K.-W. Gurgel, H. Rohling, and T. Schlick, "Low power high frequency sur-face wave radar application for ship detection and tracking", Proc. of Radar 2008 Conference, Adelaide, Australia, pp. 654-659, September 2008.

[10] K.-W. Gurgel, Y. Barbin, T. Schlick, "Radio frequency interference suppression techniques in FMCW modulated HF radars", Proc. of IEEE/OES Oceans'07 Europe, Aberdeen, Scotland, UK, June 2007.

[11] H. Rohling, "Radar CFAR thresholding in clutter and multiple target situations", IEEE Trans. Aerospace Electron. Syst., vol. AES-19, pp. 608-621, October 1983.

[12] M. G. Kendall, A. Stuart, The advanced theory of statistics, vol. 2, London: Charles Griffin and Company Ltd., 1967.

[13] A. L. Dzvonkovskaya, H. Rohling, "Target detection with adaptive power regression threshold-ing for HF radar", Proc. of CIE International Conference on Radar ICR-2006, Shanghai, China, October 2006, pp. 183-186.

[14] S. S. Blackman, Multiple-target tracking with radar applications, Dedham, MA: Artech House Inc., 1986.

[15] D.E. Barrick, J.M. Headrick, R.W. Bogle, D.D. Crombie, “Sea backscatter at HF: Interpretation and utilization of the echo”, Proc. IEEE, Vol. 62(6): pp. 673-680, 1974. 
[16] D.M. Fernandez, J.F. Vesecky, C.C. Teague, J.D. Paduan, K.E. Laws. "Ship detection with high-frequency phased array and direction-finding radar systems", Proc. of IEEE Geoscience and Remote Sensing Symposium (IGARSS '98), 1998.

[17] R. Khan, B. Gamberg, D. Power, J. Walsh, B. Dawe, W. Pearson, D. Millan, “Target detection and tracking with a high frequency ground wave radar", IEEE Journal of Oceanic Engineering, Vol. 19(4): pp. 540-548, 1994.

[18] J. Barnum, "Ship detection with high-resolution HF skywave radar", Oceanic Engineering, IEEE Journal of, Vol.11(2): pp. 196-209, 1986.

[19] J.D. Paduan, L.K. Rosenfeld, "Remotely sensed surface currents in Monterey Bay from shore-based HF-radar (CODAR)", Journal of Geophysical Research, Vol. 101: pp. 20669-20686, 1996.

[20] D.E. Barrick, P.M. Lilleboe, C.C. Teague, "Multi-station HF FMCW radar frequency sharing with GPS time modulation multiplexing", U.S. Patent SN 10/109,769.

[21] B.J. Lipa, D.E. Barrick, "Least-squares methods for the extraction of surface currents from CODAR cross-loop data: application at ARSLOE", IEEE Journal of Oceanic Engineering, Vol. OE-8: pp. 226-253, 1983.

[22] D.E. Barrick, B.J. Lipa, "Comparison of direction-finding and beam-forming in hf radar ocean surface current mapping", Phase 1 SBIR final report, Contract No. 50-DKNA-5-00092, 1996.

[23] D.E. Barrick, B.J. Lipa, "Radar angle determination with MUSIC direction finding”, U.S. Patent 5,990,834.

[24] J.T. Kohut, S.M. Glenn, "Improving HF Radar Surface Current Measurements with Measured Antenna Beam Patterns", Vol. 20(9): pp. 1303-1316, 2003.

[25] D. Gong, J.T. Kohut, S.M. Glenn, "Seasonal Climatology of Wind-Driven Circulation on the New Jersey Shelf", Journal of Geophysical Research, 2009.

[26] T. Rossby, E. Gottlieb, "The Oleander Project: Monitoring the variability of the Gulf Stream and adjacent waters between New Jersey and Bermuda." Bulletin of American Meteorology Society, Vol. 79: pp. 5-18, 1998.

[27] R.O. Schmidt, "Multiple Emitter Location and Signal Parameter Estimation", IEEE Trans. An-tennas Propagation, Vol. AP-34: pp. 276-280, 1986.

[28] D.E. Barrick, Belinda J. Lipa, P.M. Lilleboe, J. Isaacson, "Gated FMCW DF Radar and signal processing for range/Doppler/angle determination", U.S. Patent $5,361,072$.

[29] D.D. Crombie, "Doppler spectrum of sea echo at 13.56 Mc./s", Nature, Vol. 175: pp. 681-682, 1955.

[30] M.A. Sid-Ahmed, Image Processing: Theory, Algorithms and Architectures: McGraw Hill. 1994.

[31] S.J. Orfanidis, Introduction to Signal Processing. 4th ed: Prentice-Hall. 1996.

[32] H. Roarty, E. Lemus, E. Handel, S. Glenn, D. E.Barrick, and J. Isaacson, "Performance Evalu-ation of SeaSonde High-Frequency Radar for Vessel Detection," Marine Technology Society Journal, vol. 45, pp. 14-24, 2011.

[33] Arctic Council, "Arctic Marine Shipping Assesment, 2009 Report," Arctic Council, Norwegian Chairmanship, p. $190,2009$.

[34] K. Johnson, "For Coast Guard Patrol North of Alaska, Much to Learn in a Remote New Place," in New York Times, New York, 2012.

[35] J. T. Kohut, S. M. Glenn, and R. J. Chant, "Seasonal current variability on the New Jersey inner shelf," J. Geophys. Res., vol. 109, p. C07S07, 2004.

[36] R. Long, D. E. Barrick, J. L. Largier, and N.Garfield, "Wave Observations from Central California: SeaSonde Systems and In Situ Wave Buoys," Journal of Sensors, pp. 1-18, 2011.

\section{AUTHORS}

First Author - Lecturer, Tarek Ibrahim H. Melad, Training Management of Libyan Army, meladtarek@gmail.com 